\title{
Environmental Drivers of Nearshore Fish Community Composition and Size Structure in Glacially Influenced Gulf of Alaska Estuaries
}

\author{
Nina C. Lundstrom ${ }^{1} \cdot$ Anne H. Beaudreau ${ }^{1,2}$ (1) $\cdot$ Franz J. Mueter $^{1} \cdot$ Brenda Konar $^{3}$ \\ Received: 28 May 2021 / Revised: 17 January 2022 / Accepted: 2 February 2022 / Published online: 25 February 2022 \\ (c) The Author(s) 2022
}

\begin{abstract}
Coastal ecosystems in Alaska are undergoing rapid change due to warming and glacier recession. We used a natural gradient of glacierized to non-glacierized watersheds (0-60\% glacier coverage) in two regions along the Gulf of Alaska-Kachemak Bay and Lynn Canal- to evaluate relationships between local environmental conditions and estuarine fish communities. Multivariate analyses of fish community data collected from five sites per region in 2019 showed that region accounted for the most variation in community composition, suggesting that local effects of watershed type were masked by regional-scale variables. Seasonal shifts in community composition were driven largely by the influx of juvenile Pacific salmon (Oncorhynchus spp.) in late spring. Spatiotemporal differences among fish communities were partly explained by salinity and temperature, which accounted for $19.5 \%$ of the variation in community composition. We used a multi-year dataset from Lynn Canal (2014-2019) to examine patterns of mean length for two dominant species. Generalized additive mixed models indicated that Pacific staghorn sculpin (Leptocottus armatus) mean length varied along site-specific seasonal gradients, increasing gradually through the summer in the least glacially influenced sites and increasing rapidly to an asymptote of $\sim 150 \mathrm{~mm}$ in the most glacially influenced sites. Starry flounder (Platichthys stellatus) mean length was more strongly related to environmental conditions, increasing with temperature and turbidity. Together, our findings suggest that community compositions of estuarine fishes show greater variation at the regional scale than the watershed scale, but species-specific variation in size distributions may indicate differences in habitat quality across watershed types within regions.
\end{abstract}

Keywords Salmon · Groundfish · Estuary $\cdot$ Watershed $\cdot$ Glacial runoff $\cdot$ Climate change

\section{Introduction}

Global climate change is profoundly affecting estuaries, which lie at the nexus of terrestrial, freshwater, and marine ecosystems. Warming and hydrological changes have consequences for a number of estuary ecosystem services,

Communicated by Henrique Cabral

Anne H. Beaudreau

annebeau@uw.edu

1 College of Fisheries and Ocean Sciences, University of Alaska Fairbanks, 17101 Point Lena Loop Road, Juneau, AK 99801, USA

2 School of Marine and Environmental Affairs, University of Washington, 3707 Brooklyn Avenue NE, Seattle, WA 98105 , USA

3 College of Fisheries and Ocean Sciences, University of Alaska Fairbanks, PO Box 757220, Fairbanks, AK 99775, USA including nutrient transfer, erosion control, coastal protection, and habitat connectivity (Barbier et al. 2011; Elliott and Whitfield 2011). The effects of climate change on estuaries vary with estuarine morphology and the structure of surrounding watersheds, but globally, estuaries are experiencing more extreme salinities, acidification, and in some cases, warming at twice the rate of the surrounding ocean (Gillanders et al. 2011; Scanes et al. 2020). These habitat changes are driving a variety of ecological outcomes, including shifts in diversity and abundance of estuarine communities (Gillanders et al. 2011; Nyitrai et al. 2012; Teichert et al. 2017). Growth and body condition of juvenile fishes may vary with changes in temperature, salinity, and suspended sediment during the period of estuarine rearing (Sogard 1992; Lankford and Targett 1994; Lowe et al. 2015). Estuaries have low species diversity, but are home to highly adaptable organisms due to the inherently variable nature of their environment resulting from large fluctuations in temperature, salinity, and tides (Elliott and 
Whitfield 2011). Many of these organisms exist in very high densities, in part because estuaries are highly productive mixing zones (Caffrey et al. 2007). Thus, estuarine resident species may be more resilient than oceanic species to climate-driven habitat changes.

Despite many studies linking environmental drivers to community and species responses in estuaries, little is known about these processes in glacially influenced systems, particularly in high latitude regions that are experiencing rapid climate change, like the Gulf of Alaska (GOA). Glaciers along the GOA are rapidly retreating, with an estimated mass loss of 75 Gt per year (1994-2013; Larsen et al. 2015). Increased temperature and precipitation in coastal Alaska (Wendler et al. 2017) has caused increased summer runoff of cold, silty meltwater in glacierized (ice-covered) watersheds (Hood et al. 2009; O'Neel et al. 2015) and warmer water temperatures during summer low flow periods in non-glacierized watersheds (Mantua et al. 2010). The impacts of changes in runoff on estuarine habitats and communities depend, in part, on the characteristics of the watersheds draining into the nearshore marine environment (Pitman et al. 2020; Sergeant et al. 2020). Watersheds along the coast of the GOA represent a range of freshwater conditions that are driven by rain, snow, glacial melt, and low-elevation wetland runoff (Sergeant et al. 2020). Thus, assessing the effects of climate change on GOA estuarine communities requires an understanding of species-environment relationships along a gradient of glacierized to non-glacierized watersheds.

Estuaries along the GOA naturally experience a wide range of environmental conditions that affect the distribution and relative abundance of fishes that use estuaries as temporary or permanent habitat (Abookire et al. 2000; Miller et al. 2014). These characteristics may determine which species can be successful in estuaries undergoing various trajectories of change. For example, GOA estuarine residents like Pacific staghorn sculpin (Leptocottus armatus) and starry flounder (Platichthys stellatus) tolerate a range of temperatures and salinities (Morris 1960; Takeda and Tanaka 2007). In contrast, juvenile coho salmon (Oncorhynchus kisutch) prefer habitats with water temperatures less than $14.5{ }^{\circ} \mathrm{C}$ (Welsh et al. 2001). The influx of cold water from glacial watersheds during the summer may help to maintain preferred temperature ranges for some taxa, such as Pacific salmon (Oncorhynchus spp.; Fellman et al. 2014, Pitman et al. 2020), but could be stressful for warm-acclimated species. Freshwater drivers have variable ecological effects across species; for instance, high river discharge has been linked to higher densities of chum salmon (O. keta) (Kohan et al. 2013), but negatively affects recruitment of Pacific herring (Clupea pallasii) populations (Ward et al. 2017, Grimaldo et al. 2020). Glacial melt also contributes large quantities of silt to the nearshore, which provides substrate beneficial for some species of flatfishes (Abookire and Norcross 1998). Turbid river plumes can serve as a predation refuge for juvenile fishes, such as Pacific salmon (Fukuwaka and Suzuki 1998), and may be a rich feeding environment due to high concentrations of pelagic prey (St. John et al. 1992). In contrast, turbidity can reduce growth in some young-of-the-year fishes due to reduced consumption rates by visual foragers (Ljunggren and Sandstrom 2007). In assessing environmental factors influencing estuarine fish communities across a range of representative watershed types, we aim to better understand how climate change is affecting GOA estuarine ecosystems and what changes in fish communities we may expect to see in the future.

The broad goal of this study was to improve our knowledge of fish community composition and size structure in glacially influenced Alaskan estuaries undergoing rapid climate-driven change. Our first objective was to assess environmental drivers of variation in estuary fish community composition during peak periods of productivity and glacial runoff (spring and summer) in two regions of the GOA, Lynn Canal (eastern GOA) and Kachemak Bay (central GOA). In each region, we sampled five estuary sites along a non-glacial to glacial watershed gradient ( 0 to $60 \%$ glacier cover). We tested the hypothesis that community composition would show greater differences between regions than among sites within a region because of differing oceanographic and habitat features between the eastern and central GOA. Within regions, we expected strong seasonal variation in community composition, driven by shifts in habitat conditions and timing of key life history events for particular species (e.g., recruitment pulses). Our second objective was to quantify seasonal patterns of mean size for two dominant estuarine fish species (Pacific staghorn sculpin and starry flounder) using a multi-year dataset for a subset of estuary sites and determine environmental conditions explaining these patterns. These species are abundant estuarine residents that are found at our sampling site yearround, making them more likely to have growth responses that reflect local environmental conditions. We hypothesized that mean fish lengths would increase throughout the spring and summer months, reflecting a temperaturedependent growth response, and vary among sites with differing degrees of glacier coverage.

\section{Methods}

\section{Study Sites and Field Sampling}

We conducted field work in two coastal regions along the GOA: Lynn Canal near Juneau in southeastern Alaska and Kachemak Bay near Homer in southcentral Alaska (Fig. 1). Lynn Canal is a fjord-like body with substantial freshwater 


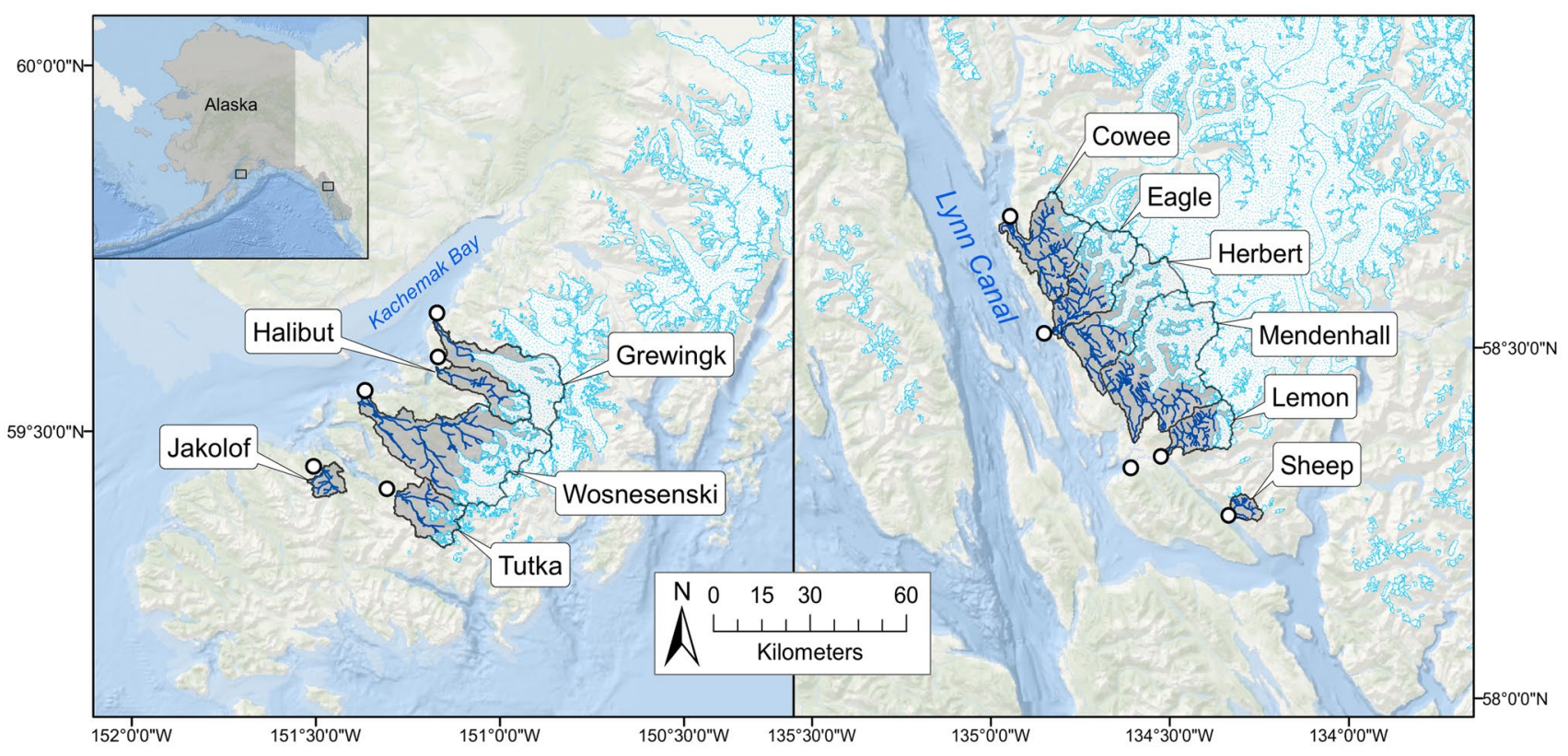

Fig. 1 Map of Gulf of Alaska (top left inset) and sites within Kachemak Bay (left) and Lynn Canal (right). Sampling sites are marked by white circles. Full names and watershed characteristics for each site are listed in Table 1. Map created by Chris Sergeant and used with permission

input, though it reaches high salinity below the freshwater lens, while Kachemak Bay is largely open with influence from GOA circulation patterns (Field and Walker 2003; Weingartner et al. 2009). Within each region, we selected five estuary sites fed by watersheds that range from approximately 0 to $60 \%$ glacier cover (Table 1; Fig. 1). While these watersheds vary in their total area, river hydrology, and the surrounding landscape, they were selected because they represented a subset of the dominant watershed-estuary types feeding the GOA (Sergeant et al. 2020). At the estuary sites, field sampling occurred at the adjacent river mouths (Table 1) on shallow sloping intertidal habitat characterized by fine-grained sediments. Lynn Canal study sites had relatively consistent substrates comprised of sand and mud, while Kachemak Bay sites included a wider range of mud to cobble substrate.

To capture fishes, we conducted monthly beach seine sampling from April through September of 2019 at each of the ten sites during the first negative low tide cycle of each month. The range of sampling months was selected to capture the period of peak freshwater discharge (Hood and Berner 2009; O'Neel et al. 2015) and the seasonality of estuary production. All sampling was conducted during spring and summer seasons, according to their astronomical start dates (i.e., spring: March 20 to June 20, 2019; summer: June 21 to September 21, 2019). Sampling was conducted using a 15.2-m long by 2.4-m deep beach seine (white stretched knotless mesh, size $1.27 \mathrm{~cm}$ ), following the seining protocols of previous studies conducted at these sites (Whitney et al. 2017, 2018; Duncan and Beaudreau 2019). The net was pulled by two people parallel to the shore for 5-6 min; then, one end was walked in an arc toward shore, effectively closing the net before it was pulled to shore. To the extent possible, six sets were conducted during the 4-5 h around low tide; occasionally, fewer sets were completed due to logistical constraints. Fish captured in the beach seine were identified to the lowest taxonomic level possible and measured to fork length or total length, depending on species, before release. To quantify temporal patterns of mean size for two dominant estuarine fish species (Objective 2), we also analyzed data previously collected at four of the Lynn Canal sites from April to September of 2014, 2016, and 2017 using nearly identical sampling protocols, as described by Whitney et al. (2017), Whitney et al. (2018), and Duncan and Beaudreau (2019). Two net types were used during 2014-2017 sampling: the same white mesh net described above $(15.2 \mathrm{~m}$ long $\times 2.4 \mathrm{~m}$ deep; $1.27 \mathrm{~cm}$ stretched knotless mesh) and a black mesh net with the same dimensions but different mesh size $(15.2 \mathrm{~m}$ long $\times 2.4 \mathrm{~m}$ deep; $0.95 \mathrm{~cm}$ stretched knotless mesh).

Water quality measurements were taken immediately following beach seining at each site on a flood stage. We used a handheld YSI Pro2030 (Xylem) instrument to measure salinity (ppt) and temperature $\left({ }^{\circ} \mathrm{C}\right)$ at three evenly spaced stations along an approximately $100 \mathrm{~m}$ transect perpendicular to the beach, beginning just off the beach from the seining site (station 1), $50 \mathrm{~m}$ off the beach (station 2), and $100 \mathrm{~m}$ off the beach (station 3). At each station, water parameters were measured at depths of $1 \mathrm{~m}$ and $5 \mathrm{~m}$ (if bottom depth allowed). Surface water samples were collected at each station and brought back to the lab to measure turbidity in 
Table 1 Estuary site information for each Gulf of Alaska region. Estuary sampling at the Eagle River site (also known as Eagle Beach) is downstream of the confluence of the Eagle and Herbert rivers, so both watersheds are included in the table. Mean summer discharge was calculated as the average daily discharge for June-September 2019. Discharge for the Eagle and Herbert rivers is based on modeled values for the total discharge of both rivers. Mean summer temperature, salinity, and turbidity were calculated as average values recorded from May to September 2019. Mean summer catch per unit effort (CPUE) and species richness per unit effort (RPUE) were calculated as the average number of fish or average number of species per fiveminute seine set for May-September 2019

\begin{tabular}{|c|c|c|c|c|c|c|c|c|c|}
\hline Estuary site & $\begin{array}{l}\text { Percent } \\
\text { glacierized } \\
(\%)\end{array}$ & $\begin{array}{l}\text { Glacier } \\
\text { area } \\
\left(\mathbf{k m}^{2}\right)\end{array}$ & $\begin{array}{l}\text { Water- } \\
\text { shed area } \\
\left(\mathbf{k m}^{2}\right)\end{array}$ & $\begin{array}{l}\text { Mean }(\mathrm{SD}) \\
\text { summer } \\
\text { discharge }\left(\mathrm{m}^{3} / \mathrm{s}\right)\end{array}$ & $\begin{array}{l}\text { Mean (SD) } \\
\text { summer } \\
\text { temperature }\left({ }^{\circ} \mathrm{C}\right)\end{array}$ & $\begin{array}{l}\text { Mean (SD) } \\
\text { summer } \\
\text { salinity (ppt) }\end{array}$ & $\begin{array}{l}\text { Mean (SD) } \\
\text { summer } \\
\text { turbidity (NTU) }\end{array}$ & $\begin{array}{l}\text { Mean } \\
\text { summer } \\
\text { CPUE }\end{array}$ & $\begin{array}{l}\text { Mean } \\
\text { summer } \\
\text { RPUE }\end{array}$ \\
\hline \multicolumn{10}{|l|}{ Kachemak Bay } \\
\hline Jakolof Bay & 0 & 0 & 18.9 & $0.3(0.2)$ & $9.4(2.6)$ & $30.8(2.1)$ & $2.7(1.2)$ & 19.4 & 3.6 \\
\hline Tutka Bay & 8 & 5 & 66.0 & $7.7(4.5)$ & $9.6(3.0)$ & $28.5(4.3)$ & $4.0(3.3)$ & 10.1 & 2.6 \\
\hline Halibut Cove & 16 & 9 & 55.6 & $10.1(8.7)$ & $10.0(2.9)$ & $28.7(2.5)$ & $4.7(3.2)$ & 9.2 & 3.6 \\
\hline $\begin{array}{l}\text { Wosnesenski } \\
\text { River estuary }\end{array}$ & 27 & 69 & 257.0 & $105.0(38.4)$ & $9.6(2.6)$ & $28.8(3.5)$ & $12.5(10.2)$ & 31.6 & 4.0 \\
\hline $\begin{array}{l}\text { Grewingk } \\
\text { River estuary }\end{array}$ & 60 & 67 & 112.0 & $47.4(18.0)$ & $10.7(3.1)$ & $27.6(4.0)$ & $12.7(32.6)$ & 7.0 & 1.7 \\
\hline \multicolumn{10}{|l|}{ Lynn Canal } \\
\hline $\begin{array}{l}\text { Sheep Creek } \\
\text { estuary }\end{array}$ & 0 & 0.03 & 15.5 & $1.3(1.6)$ & $10.0(2.6)$ & $22.1(6.0)$ & $2.9(3.1)$ & 32.7 & 4.1 \\
\hline $\begin{array}{l}\text { Cowee Creek } \\
\text { estuary }\end{array}$ & 10 & 12 & 119.0 & $10.1(5.3)$ & $10.9(4.0)$ & $25.3(6.6)$ & $2.2(1.6)$ & 20.0 & 3.0 \\
\hline $\begin{array}{l}\text { Lemon Creek } \\
\text { estuary }\end{array}$ & 25 & 15 & 62.6 & $11.5(8.8)$ & $9.9(2.7)$ & $11.8(5.3)$ & $8.1(15.1)$ & 57.3 & 4.3 \\
\hline $\begin{array}{l}\text { Eagle River } \\
\text { estuary }\end{array}$ & 41 & 117 & 285.0 & $75.5(29.4)$ & $11.0(4.1)$ & $25.2(5.4)$ & $1.8(1.7)$ & 32.8 & 3.2 \\
\hline Eagle & 41 & 53 & 127.0 & $33.1(13.1)$ & & & & & \\
\hline Herbert & 41 & 64 & 158.0 & $41.4(16.3)$ & & & & & \\
\hline $\begin{array}{l}\text { Mendenhall } \\
\text { River estuary }\end{array}$ & 54 & 124 & 228.0 & $87.8(35.7)$ & $11.9(2.7)$ & $22.5(4.4)$ & $5.8(4.9)$ & 54.9 & 4.6 \\
\hline
\end{tabular}

Nephelometric Turbidity Units (NTU; Hach 2100P Turbidimeter). Discharge data were obtained from the US Geological Survey and the University of Alaska Southeast Environmental Science Department stream gages (USGS 2020).

\section{Data Analysis}

To assess environmental drivers of variation in estuary fish community composition across sites and regions (Objective 1), we used fish community and environmental data from 2019 collected at all ten study sites in Lynn Canal and Kachemak Bay (Table 1). To quantify temporal patterns of fish size (Objective 2), we used fish length data and environmental data from four years $(2014,2016,2017,2019)$. Because the Kachemak Bay sites had not been sampled prior to 2019, we used length data from four Lynn Canal sites only (all except Lemon Creek; Table 1). Invertebrates, which were captured infrequently, were excluded from analyses. Larval fish and fish smaller than $20 \mathrm{~mm}$ in length were also excluded from analyses because their catchability was inconsistent due to their small size relative to the mesh size. Juvenile salmonids were aggregated to the genus Oncorhynchus, and members of the family Osmeridae were aggregated due to difficulty of field identification. Environmental data (i.e., temperature, salinity, and turbidity) were averaged for each sampling event (site and date combination). River discharge data recorded in 15-min intervals were averaged over the sampling date to generate a mean daily discharge value, thus maintaining consistency with the temporal resolution at which other environmental variables were measured.

To prepare the catch data for analysis, we calculated species-specific catch-per-unit-effort (CPUE) by dividing the number of individuals for a given species and seine set by the set duration (minutes). This number was multiplied by five to generate a species-specific CPUE for a standard 5-min set. A mean catch-per-set (hereafter, "mean CPUE") was calculated across all sets in a sampling event (site $\times$ month). We also calculated relative species richness (richness per unit effort, RPUE) as the number of unique taxa caught per 5-min set, averaged across sets in a sampling event. Only sets without sampling errors (e.g., net stuck on a rock or technician stuck in the mud) were included in CPUE and RPUE calculations. We performed a 2-way nested ANOVA to test for differences in mean values of RPUE and CPUE among sites (nested within region) and months. 
We assessed spatiotemporal variation in fish community composition using multivariate ordination (Objective 1). Mean CPUE, calculated for each sampling event $(n=55)$, was fourth-root transformed to down-weight the influence of highly abundant species (Clarke et al. 2014). We calculated pairwise Bray-Curtis dissimilarities between sampling events and performed non-metric multidimensional scaling (NMDS) ordination in as many dimensions as needed to reduce the stress below $20 \%$ using the "vegan" package in $\mathrm{R}$ (Oksanen et al. 2019). We plotted the first two dimensions of the NMDS ordination to illustrate the variability in species composition within and between regions. To help interpret differences in species composition, we illustrated the strength of the correlations between ordination axes and the fourth root transformed CPUE of individual species as vectors in the ordination diagram (Clarke et al. 2014). Vectors were scaled proportionally to their correlation with each axis and only species with squared Pearson's correlations exceeding $0.2\left(R^{2}>0.2\right)$ are shown. Each vector indicates the direction of the strongest gradient in species abundance for a given species (e.g., Mahardja et al. 2017). We conducted an analysis of dispersion (Anderson 2001) to determine if the multivariate dispersion of samples, which reflects variability in species composition, differed between regions.

We then evaluated relationships between fish community composition and environmental conditions, using environmental data (temperature, salinity, turbidity, and discharge) for each sampling event. We used vector-fitting analysis to overlay the environmental variables onto the ordinations of the fish communities ("envfit" function in the R package "vegan"; Oksanen et al. 2019). The vectors show the directions in which the environmental variables are most strongly correlated with fish community composition in ordination space. Finally, we ran a permutational multivariate analysis of variance (PERMANOVA) on the Bray-Curtis distance matrix to test for the fixed effects of region (2 levels), sampling date, and each environmental variable (temperature, salinity, turbidity, river discharge) on species composition ( $n=55$ sampling events) using the "adonis2" function in "vegan" (Oksanen et al. 2019). Site was also included as a random effect to account for variability among sites within regions. We then performed a PERMANOVA separately for each region to test for the fixed effects of site, sampling date, and each environmental variable on fish communities in Lynn Canal ( $n=30$ sampling events) and Kachemak Bay ( $n=25$ sampling events). Partial $R^{2}$ values were calculated as the additional variation explained by a given variable, after the effects of all other variables have been accounted for (i.e., "marginal" effect obtained via "adonis2").

We used the multi-year Lynn Canal dataset to quantify variation in mean length of two dominant species (Objective 2): Pacific staghorn sculpin (hereafter, staghorn sculpin) and starry flounder. We chose these species because they were the most abundant species at Lynn Canal sites across all months and years of sampling. We measured the first 30-50 (depending on sampling year) randomly selected individuals in each set. For each species, we calculated a mean length for each seine set and evaluated changes in mean length across months, years, and sites. We used overall mean length because there were not consistently clear cohorts of staghorn sculpin or starry flounder that we could identify based on length frequency histograms (Figs. S1, S2). We used generalized additive mixed models (GAMMs) with a normal distribution to model $\log$ (length) as a function of space/time effects and additive local environmental effects ("mgcv" package in R, Wood 2011). A log-transformation of the response was determined based on a Box-Cox procedure (Weisberg 1985) and inspection of diagnostic residual and probability plots did not indicate heteroscedasticity or non-normality following transformation. We were primarily interested in the mean spatial and seasonal patterns; therefore, we tested for fixed effects of site (10 levels) and day of year, as well as their interaction, and included a random year effect (4 levels) to account for possible differences in mean length between years (e.g., due to cohort effects or differences in mean growth conditions). The site $\times$ day of year interaction was included because preliminary analyses suggested that seasonal patterns varied among sites.

A set of 12 candidate models was generated for each species (Table S1): combinations of predictors were split into two sets of models, each representing a different set of hypotheses regarding drivers of fish length (Burnham and Anderson 2002). One set of candidate models included only space/time predictors (year as random effect, site $\times$ day of year interaction) and one set included only environmental predictors (temperature, salinity, turbidity). We did not include discharge as a potential predictor because it was not available for all sites and years. By separating space/time parameters and environmental parameters into separate a priori model sets, we avoid the inclusion of confounded variables like day of year and temperature in the same model and reduce the risk of model overfitting, which can arise from inclusion of a large number of predictor variables in the full model (Burnham and Anderson 2002). Net type was included as a random effect in all models to control for potential differences in selectivity between the white mesh and black mesh seines. All continuous variables (day of year, temperature, salinity, turbidity) were standardized in the regression to have a mean of 0 and a standard deviation of 1 and modeled using thin plate regression splines. Standardization was performed to facilitate graphical comparisons of the partial effects of predictor variables on mean length, but does not otherwise affect results. Model selection was performed using Akaike's information criterion (AIC), where models within two units of the lowest AIC were considered to perform equivalently (Burnham and Anderson 2002). We 
calculated Akaike parameter weights for parameter $j$ as the sum of model Akaike weights (relative likelihoods) across all models that included parameter $j$ (Burnham and Anderson 2002).

\section{Results}

\section{Summary of Environmental Conditions and Catch Data}

Temperature measured at our study sites in 2019 varied seasonally, following a similar parabolic trend in both regions, with lowest temperatures in April and a peak in July (Fig. 2).
Salinity showed a more marked decline from spring to midsummer at Lynn Canal sites compared to the more temporally stable salinities at Kachemak Bay sites and turbidity varied without a clear seasonal trend (Fig. 2). Mean summer temperatures were similar in Kachemak Bay and Lynn Canal, whereas mean salinity was significantly higher at the Kachemak Bay sites (mean summer salinity $=28.9 \mathrm{ppt}$ ) compared to the Lynn Canal sites (mean summer salinity $=21.4$ ppt) (Table 1; Welch's $t=-9.32, \mathrm{df}=224.4, P<0.0001$ ). Mean summer discharge was higher in glacierized systems compared to less glacierized watersheds (Table 1; Fig. 2). We caught and identified over 13,000 individual fish (38 species from 15 families) over the course of 60 sampling events and 360 seine sets in the 2019 sampling season. After
Fig. 2 Seasonal patterns in environmental variables from April to September 2019 in Kachemak Bay and Lynn Canal estuaries. From top to bottom: temperature, salinity, turbidity, river discharge. Points show the mean of monthly measurements taken at depths of $1 \mathrm{~m}$ and $5 \mathrm{~m}$ below the surface at three stations along a 100-m transect perpendicular to the beach where seining was conducted for temperature and salinity; whiskers are \pm 1 SD. Discharge is a mean daily value from stream gages. Kachemak Bay sites are the Grewingk River estuary (GR), Wosnesenski River estuary (WR), Halibut Cove (HC), Tutka Bay (TB), and Jakolof Bay (JB). Lynn Canal sites are the Mendenhall River estuary (MR), Eagle River estuary (ER), Lemon Creek estuary (LC), Cowee Creek estuary (CC), and Sheep Creek estuary (SC)
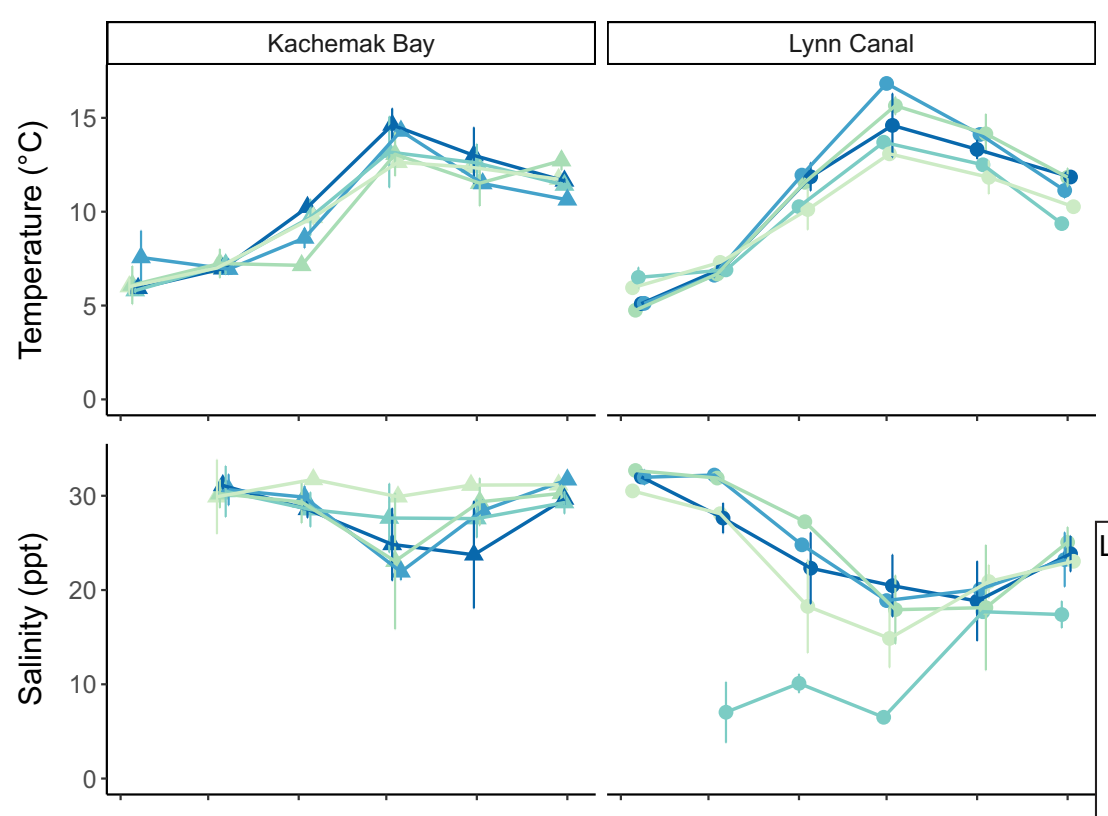

Lynn Canal sites

- MR

- ER

- LC

- CC

- SC

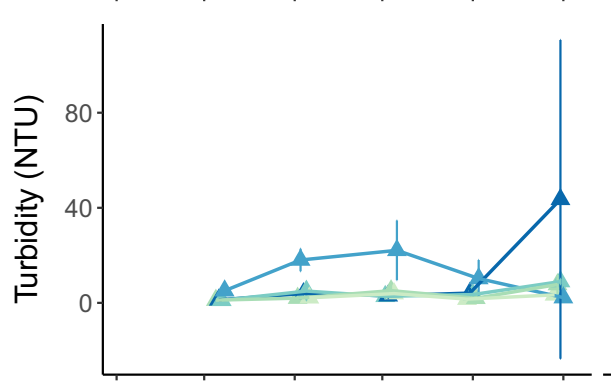

Kachemak

Bay sites

$\pm \mathrm{GR}$

\pm WR

$\pm \mathrm{HC}$

$+\mathrm{TB}$

$-\mathrm{JB}$

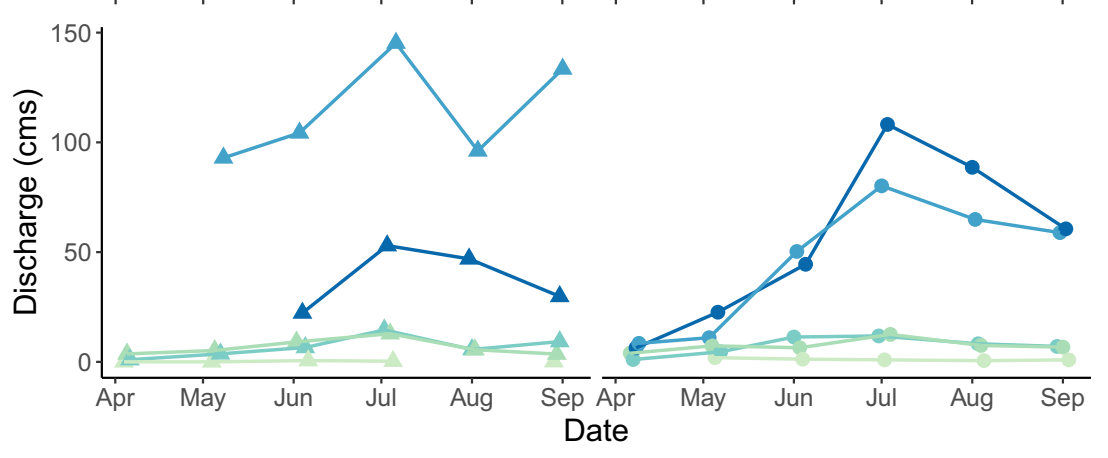


eliminating sets for which CPUE calculations were unreliable due to sampling issues, we were left with 308 sets from 55 sampling events for analysis. Over $85 \%$ of the total catch was attributed to four families: Cottidae, Gadidae, Pleuronectidae, and Salmonidae (Table 2). The families Cottidae and Pleuronectidae contributed substantially to the catches at all Lynn Canal sites throughout the sampling season. In Kachemak Bay, catches were less dominated by one or two families, but included fishes not caught in Lynn Canal, such as several cod species (Gadidae). Gunnels (Pholidae) were also caught more consistently in Kachemak Bay. In both regions, juvenile Pacific salmon were caught in high numbers, especially in May and June; however, $68 \%$ of the Pacific salmon in Kachemak Bay were caught at one site (Tutka Bay), whereas the catch in Lynn Canal was more evenly distributed across sites (Table 2).

Species richness per unit effort (RPUE) differed significantly between regions $(F=4.2, \mathrm{df}=1, P=0.047)$, among months $(F=3.7, \mathrm{df}=5, P=0.008)$, and among sites within region $(F=3.2, \mathrm{df}=8, P=0.007$; Table $\mathrm{S} 2)$. Catch per unit effort (CPUE) also differed significantly between regions $(F=25.1, \mathrm{df}=1, P<0.001)$, among months $(F=4.3, \mathrm{df}=5$, $P=0.003)$, and among sites within region $(F=4.3, \mathrm{df}=8$, $P=0.001$; Table S2). Mean ( \pm SD) RPUE and CPUE across May through September sampling periods were higher in Lynn Canal (RPUE 3.82 \pm 1.22 , CPUE 39.6 \pm 24.4 ) compared to Kachemak Bay (RPUE $3.01 \pm 1.43$, CPUE
$15.3 \pm 13.3)$. In Kachemak Bay, mean RPUE and mean CPUE were higher in June and July compared to other months (Table S2) and varied among sites, ranging from 1.7 to 3.9 unique species and 7.3 to 32.1 fish per 5-min seine set (mean across May-September 2019; Table 1). In Lynn Canal, mean RPUE and mean CPUE peaked in May and June (Table S2) and varied among sites, ranging from 3.0 to 4.6 unique species and 20.0 to 58.6 fish per 5 -min seine set (mean across May-September 2019; Table 1).

\section{Environmental Drivers of Fish Community Composition}

Regional differences and seasonal differences in fish community composition were highly significant $(P=0.0002$ for both). Fish communities were more similar within Lynn Canal than they were within Kachemak Bay, based on heterogenous dispersions between regions (analysis of dispersion: $F=7.665, P=0.008$ ). The NMDS provided a good representation of the community differences in three dimensions based on a stress value of 0.14 . The first axis of the NMDS primarily separated regions (Fig. 3), with species vectors $\left(R^{2}>0.2\right)$ indicating that staghorn sculpin and starry flounder were more strongly associated with Lynn Canal sites and great sculpin (Myoxocephalus polyacanthocephalus) were more strongly associated with Kachemak Bay sites (Fig. 3).
Table 2 Percentage of total 2019 catch per site by fish family. Kachemak Bay sites include Jakolof Bay (JB), Tutka Bay (TB), Halibut Cove (HC), Wosnesenski River estuary (WR), Grewingk River estuary (GR). Lynn Canal sites include Sheep Creek estuary (SC), Cowee
Creek estuary (CC), Lemon Creek estuary (LC), Eagle River estuary (ER), and Mendenhall River estuary (MR). Mean \% is the average percentage of the catch contributed by each fish family across sites

\begin{tabular}{|c|c|c|c|c|c|c|c|c|c|c|c|c|}
\hline \multirow[b]{2}{*}{ Taxon } & \multicolumn{6}{|c|}{ Kachemak Bay } & \multicolumn{6}{|c|}{ Lynn Canal } \\
\hline & $\mathrm{JB}$ & $\mathrm{TB}$ & $\mathrm{HC}$ & WR & GR & Mean $\%$ & $\mathrm{SC}$ & $\mathrm{CC}$ & LC & ER & MR & Mean $\%$ \\
\hline Agonidae & 0.0 & 0.0 & 0.0 & 0.0 & 0.0 & 0.0 & $<0.1$ & 0.3 & 0.0 & 0.1 & $<0.1$ & 0.1 \\
\hline Ammodytidae & 0.0 & 0.0 & 0.0 & 0.1 & 0.0 & 0.0 & 0.0 & 2.7 & 0.0 & 0.2 & 0.0 & 0.6 \\
\hline Clupeidae & 0.0 & 0.0 & 0.0 & 9.4 & 69.0 & 15.7 & 0.3 & 0.2 & 0.2 & 0.7 & 1.4 & 0.5 \\
\hline Cottidae & 1.9 & 22.4 & 42.0 & 7.9 & 16.3 & 18.1 & 32.4 & 49.7 & 73.6 & 67.8 & 55.4 & 55.8 \\
\hline Cyclopteridae & 0.0 & 0.0 & 0.0 & 0.0 & 0.0 & 0.0 & 0.0 & 0.0 & 0.0 & 0.0 & $<0.1$ & 0.01 \\
\hline Gadidae & 88.2 & 0.3 & 3.2 & 19.2 & 0.3 & 22.2 & 0.0 & 0.0 & 0.0 & 0.0 & 0.0 & 0.0 \\
\hline Gasterosteidae & 0.0 & 0.0 & 0.0 & 0.0 & 0.0 & 0.0 & 0.3 & 0.2 & 0.5 & 0.0 & $<0.1$ & 0.2 \\
\hline Hexagrammidae & 1.1 & 0.3 & 6.4 & 0.0 & 1.6 & 1.9 & 0.0 & 0.3 & 0.0 & 0.1 & 1.2 & 0.3 \\
\hline Liparidae & 0.0 & 0.0 & 0.4 & 0.1 & 0.6 & 0.2 & $<0.1$ & 0.2 & $<0.1$ & $<0.1$ & 0.0 & 0.1 \\
\hline Osmeridae & 0.0 & 0.0 & 0.4 & 39.5 & 0.0 & 8.0 & 2.4 & 1.2 & 0.0 & 5.3 & 7.9 & 3.4 \\
\hline Pholidae & 2.2 & 3.8 & 6.8 & 0.1 & 1.3 & 2.8 & 0.0 & 5.3 & 0.0 & 0.1 & 0.2 & 1.1 \\
\hline Pleuronectidae & 1.0 & 5.0 & 17.2 & 3.9 & 0.3 & 5.5 & 20.6 & 18.6 & 10.3 & 11.2 & 10.0 & 14.1 \\
\hline Salmonidae & 1.4 & 68.2 & 21.6 & 19.0 & 10.6 & 24.2 & 43.9 & 20.8 & 15.5 & 13.6 & 21.8 & 23.1 \\
\hline Stichaeidae & 4.1 & 0.0 & 2.0 & 0.8 & 0.0 & 1.4 & 0.0 & 0.5 & 0.0 & 0.9 & 1.9 & 0.7 \\
\hline Syngnathidae & 0.1 & 0.0 & 0.0 & 0.0 & 0.0 & 0.0 & 0.0 & 0.0 & 0.0 & 0.0 & 0.0 & 0.0 \\
\hline
\end{tabular}


The second NMDS axis indicated seasonal effects, which were largely driven by the higher abundance of juvenile Pacific salmon in May and June, based on vector analysis. For these ordinations, we show only two dimensions in the plots because the third NMDS axis was not associated with an obvious environmental or space gradient. Communities differed among sampling events (i.e., month $\times$ site combinations) $\left(F=2.34, R^{2}=0.18, P=0.001\right)$, with a clear seasonal change in species composition along the second NMDS axis (Fig. S3). Within Lynn Canal, the Lemon Creek sampling events separated slightly from the other sites due to lower abundances of juvenile salmon, osmerids, and rock sole (Lepidopsetta bilineata) at Lemon Creek (Fig. 3). Within Kachemak Bay, the Jakolof Bay and Wosnesenski River sites were more strongly associated with snake prickleback (Lumpenus sagitta) and Pacific tomcod (Microgadus Proximus) (Fig. 3).

Across regions, effects of temperature and salinity on species composition were significant, based on a PERMANOVA (Fig. 3). Salinity had greater explanatory power, accounting for up to $12 \%$ of the variability in species composition ( $F=7.37$, partial $\left.R^{2}=0.12, P=0.001\right)$, compared to temperature $\left(F=5.14\right.$, partial $\left.R^{2}=0.075, P=0.001\right)$. Turbidity and discharge did not have a significant effect on species composition for both regions combined $(P=0.7$ and $P=0.1$, respectively). Within Lynn Canal, fish community composition differed significantly across sites $\left(F=1.9\right.$, partial $R^{2}=0.21$, $P=0.007)$ and sampling date $\left(F=5.7\right.$, partial $R^{2}=0.15$, $P=0.001)$ and, among environmental variables, only the effects of salinity $\left(F=2.7\right.$, partial $\left.R^{2}=0.09, P=0.005\right)$ and temperature $\left(F=2.8\right.$, partial $\left.R^{2}=0.09, P=0.004\right)$ were significant. After accounting for the effects of the environmental variables, there was no longer a significant site effect $(P=0.43)$, but the effect of sampling date remained highly significant $\left(F=4.4\right.$, partial $\left.R^{2}=0.12, P=0.001\right)$. Among Lynn Canal sites, Sheep Creek and Lemon Creek had the lowest overall species richness (i.e., number of unique taxa across all sampling events), but high dominance of sculpins and flatfishes (Table 2). Within Kachemak Bay, fish community composition differed significantly across sites $(F=3.2$, partial $\left.R^{2}=0.35, P=0.001\right)$ and sampling date $(F=5.0$, partial $\left.R^{2}=0.13, P=0.001\right)$ and the effects of temperature $(F=2.0$, partial $\left.R^{2}=0.08, P=0.047\right)$ and river discharge $(F=2.5$, partial $\left.R^{2}=0.10, P=0.01\right)$ were significant. After accounting for the effects of the significant environmental variables, there were still significant effects of both site $(F=3.0$, partial $\left.R^{2}=0.32, P=0.001\right)$ and sampling date $(F=3.4$, partial $\left.R^{2}=0.09, P=0.002\right)$. In Kachemak Bay, the dominant groups varied among sites. For example, clupeids and gadids made up the highest proportion of the catches at the Grewingk River and Jakolof Bay sites, respectively (Table 2).

\section{Environmental Drivers of Size for Dominant Species in Lynn Canal Estuaries}

Across all years $(2014,2016,2017,2019)$, we measured 11,337 staghorn sculpins and 7848 starry flounders at four sites in Lynn Canal (Cowee Creek, Eagle River, Mendenhall River, Sheep Creek). Staghorn sculpins were most abundant at the most glacierized sites (Mendenhall, Eagle) across all years, whereas starry flounder were more evenly distributed across sampling sites; however, there was more interannual variation in starry flounder catch, with substantially higher numbers in 2016 and 2017 compared to 2014 and 2019 (Fig. S2). Seasonal patterns in staghorn sculpin size composition and mean size varied among sites and years in Lynn Canal (Figs. 4, S4). The best model explaining variation in mean staghorn sculpin length included year, the interaction of site and day of year, and net, and had an Akaike model weight of 1 (Table 3; Table S1). Year, day of year, and site $\times$ day of year were all important predictors, with parameter weights of 1 . For all years, length increased with day of year before reaching an asymptote around June, but exhibited variable patterns across sites (Fig. S5). The environmental variables on their own were poor predictors of mean length, with parameter weights close to zero (Table 3; Table S1). Mean length of staghorn sculpins gradually increased from less than $100 \mathrm{~mm}$ in April to nearly $200 \mathrm{~mm}$ by the end of summer in Sheep Creek and Cowee Creek estuaries, while mean lengths of Eagle River and Mendenhall River fish showed a rapid increase from $100 \mathrm{~mm}$ in April to a peak in June, then stabilized around $150 \mathrm{~mm}$ by July (Fig. 4). For starry flounder, only Sheep Creek fish showed consistent increases in mean length through the spring and summer. Starry flounder mean lengths at Cowee Creek, Mendenhall River, and Eagle River estuaries approached asymptotes of 150-200 mm mid-summer, depending on the site (Fig. 5). The models for mean length also differed from the staghorn sculpin models in that environmental predictors were more important than space/time factors. Mean size did not vary among years (Fig. S6). Starry flounder length increased slightly and approximately linearly with temperature and more steeply with turbidity (from 110 to $120 \mathrm{~mm}$ and from 110 to $245 \mathrm{~mm}$ over the range of temperatures and turbidities, respectively; Fig. S7). The best model included all three environmental covariates (Figs. S8-S10) and net type and had a model weight of 0.56 ; the model including only temperature, turbidity, and net type also performed within 2 units of the lowest AIC value, with a model weight of 0.44 (Table 3; Table S1). Temperature and turbidity 

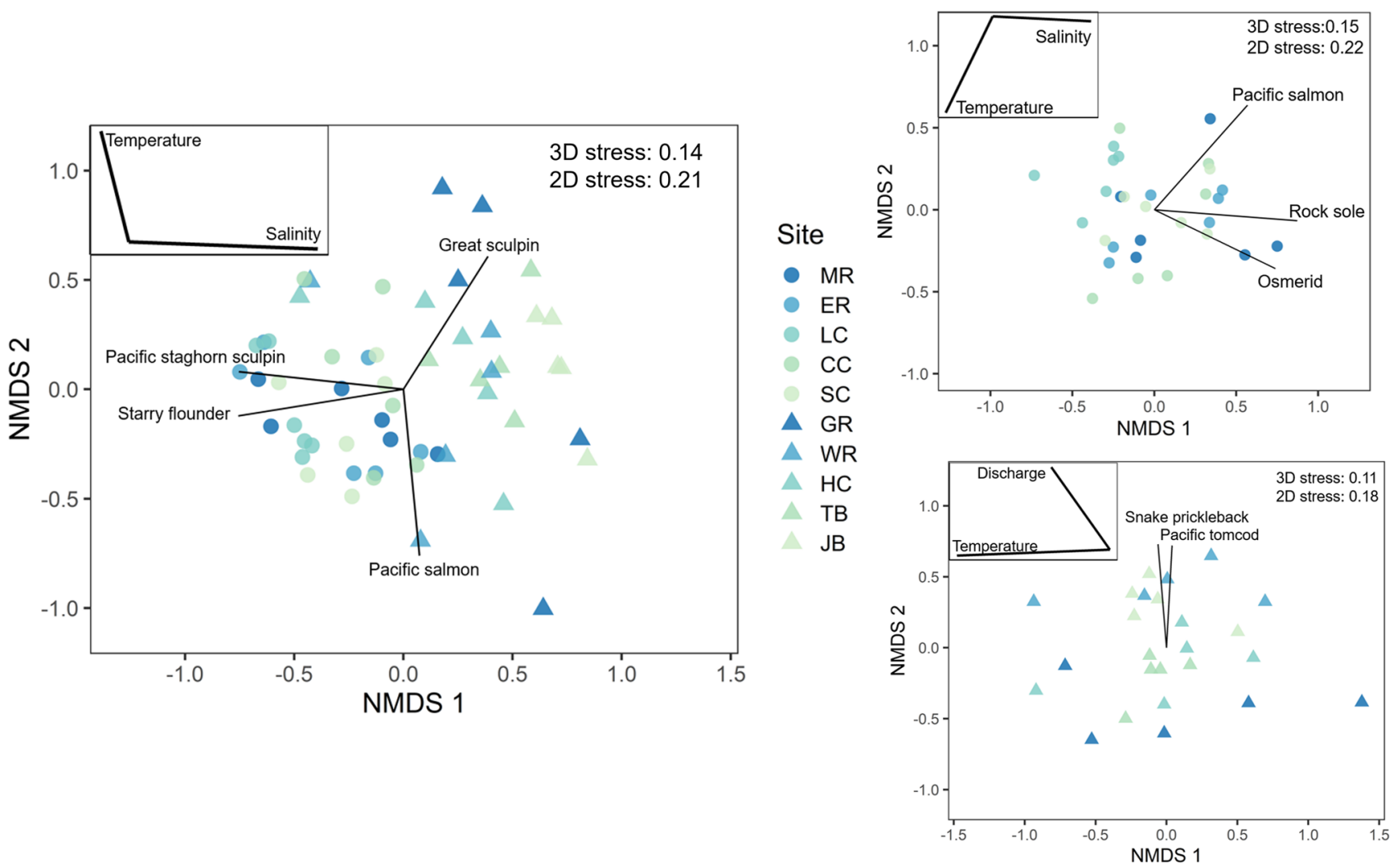

Fig. 3 Non-metric multidimensional scaling (NMDS) ordination performed on Bray-Curtis dissimilarities of sampled fish communities in Gulf of Alaska estuaries. Each point represents the fish community caught during a sampling event (month $\times$ site combination, $n=55$ sampling events). Left panel shows ordination of all sampling events, right top panel shows only Lynn Canal sampling events, and right bottom panel shows only Kachemak Bay sampling events. Points are color coded by site (Lynn Canal sites: circles, Kachemak Bay sites:

were highly influential predictors, with parameter weights close to 1 , while salinity was moderately important with a parameter weight of 0.59 .

\section{Discussion}

This study improves our understanding of how estuarine habitats and fish communities in the GOA are affected by dynamic watersheds within glacierized landscapes. While other studies have examined environmental factors, including temperature, salinity, substrate, and depth, that structure GOA nearshore fish communities (Moles and Norcross 1995; Norcross et al. 1995, 1999; Abookire et al. 2000; Pirtle et al. 2012; Miller et al. 2014; Guo 2019), ours is the first to sample estuaries along a glacial to non-glacial watershed gradient in two distinct regions of the GOA. This allowed us to examine a wide range of environmental conditions at river deltas along a gradient of glacial influence and their triangles), with vectors showing the directional influence of the fish species (only correlations with $R^{2}>0.5$ are shown) and environmental variables in the top left corners (only correlations with $R^{2}>0.2$ are shown). Kachemak Bay sites are the Grewingk River estuary (GR), Wosnesenski River estuary (WR), Halibut Cove (HC), Tutka Bay (TB), and Jakolof Bay (JB). Lynn Canal sites are the Mendenhall River estuary (MR), Eagle River estuary (ER), Lemon Creek estuary (LC), Cowee Creek estuary (CC), and Sheep Creek estuary (SC)

effects on fish community structure. Temperature, salinity, and turbidity varied among sites within regions, but not in a consistent way along the glacial to non-glacial gradient. In particular, estuary turbidity values were highly variable and much lower than turbidity in adjacent streams, suggesting that watershed effects may be quickly diluted through mixing with oceanic waters in the estuary. For example, turbidity values in the estuary at the Mendenhall and Eagle sites were roughly an order of magnitude lower than turbidity values in the respective rivers, based on previous sampling $(>50 \mathrm{NTU}$; Hood and Berner 2009). We found differences in community structure between regions and among sites, which were partly explained by contrasting salinities, temperatures, and discharge levels. Regional differences were greater than site and seasonal differences within a region. Additionally, strong variation in fish community composition and size structure across months aligns with our understanding of high latitude ecosystems as seasonally dynamic, due to a combination of temperature-dependent growth, recruitment events, 
Fig. 4 Mean Pacific staghorn sculpin lengths over spring and summer for Lynn Canal sites, 2014-2019. Points are color coded by mean water temperature measured on the sampling date. Solid lines are fitted loess regression smoothing functions to visualize seasonal trends. Gray bands show the $95 \%$ confidence interval

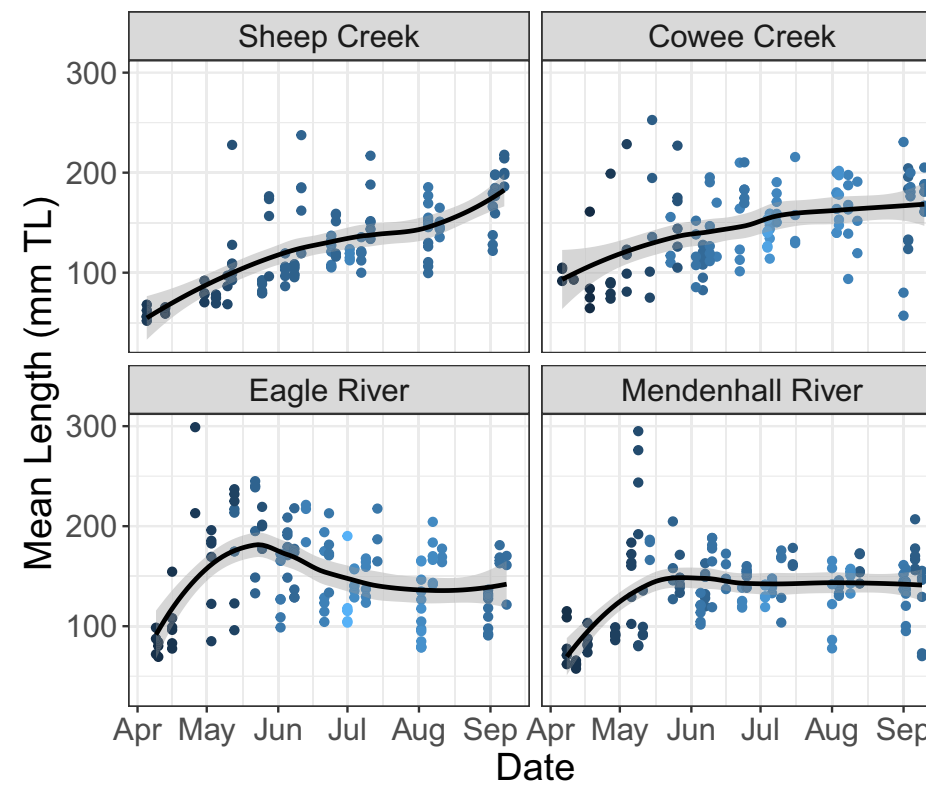

Temperature $\left({ }^{\circ} \mathrm{C}\right)$

15.0

12.5

10.0

7.5

5.0 and migration of transient species (e.g., Beaudreau et al. in review, Bienfang and Ziemann 1995).

\section{Patterns and Environmental Drivers of Fish Community Composition}

We found striking differences in species composition between the Lynn Canal and Kachemak Bay regions. Lynn Canal communities were consistently dominated by staghorn sculpin and starry flounder, whereas Kachemak Bay communities included a more variable assemblage of species. Similar to our findings, a previous study of nearshore fish communities in Kachemak Bay found a high prevalence of saffron cod (Eleginus gracilis) and Pacific tomcod (Microgadus proximus) (Abookire et al. 2000). Heterogeneous dispersions between

Table 3 Model summaries for generalized additive models of the logtransformed lengths of Pacific staghorn sculpin and starry flounder. In total, 12 models were evaluated for each species, with all combinations of the space/time predictors (site, day of year, year) and all combinations of the environmental predictors (temperature, salinity, and turbidity); net was included as a random effect in all models. Only regions complicate the interpretation of the PERMANOVA results because it can be difficult to determine whether a rejection of the null hypothesis represents significant differences between the centroids of the two regions, or differences in the spread of the points (Anderson and Walsh 2013). However, PERMANOVA is relatively robust to heterogeneity in balanced study designs (Anderson and Walsh 2013) and qualitative differences in species composition between regions support statistical results. Multivariate analyses of algal and invertebrate communities sampled at the same sites in 2019 also showed greater variation in ecological communities among Kachemak Bay sites compared to Lynn Canal sites (McCabe 2021).

Vector fitting analyses indicated that differences between regions may be attributed to contrasting environmental conditions, particularly salinity. We found considerably higher

the best fit models $(\Delta \mathrm{AIC} \leq 2)$ and full space/time and environmental models are shown; null models were included as a point of comparison. $K$ is the total number of parameters estimated, AIC is Akaike's information criterion, $\triangle \mathrm{AIC}$ is calculated as the difference in AIC between each model and the model with the lowest AIC, and $w_{i}$ is the model weight

\begin{tabular}{|c|c|c|c|c|c|c|}
\hline Model Number & Model Parameters & $K$ & AIC & $\Delta \mathrm{AIC}$ & $w_{i}$ & $R^{2}$ \\
\hline \multicolumn{7}{|c|}{ Pacific staghorn sculpin } \\
\hline 1 & Year + site $\times$ day of year + net & 14 & 151.69 & 0 & 1 & 0.307 \\
\hline 2 & Temperature + salinity + turbidity + net & 6 & 232.23 & 80.53 & 0 & 0.185 \\
\hline 3 & Null & 2 & 386.14 & 234.45 & 0 & 0 \\
\hline \multicolumn{7}{|l|}{ Starry flounder } \\
\hline 1 & Temperature + salinity + turbidity + net & 6 & 588.69 & 0 & 0.56 & 0.100 \\
\hline 2 & Temperature + turbidity + net & 5 & 589.15 & 0.45 & 0.44 & 0.101 \\
\hline 3 & Year + site $\times$ day of year + net & 14 & 884.84 & 296.15 & 0 & 0.224 \\
\hline 4 & Null & 2 & 1086.0 & 497.34 & 0 & 0 \\
\hline
\end{tabular}


salinities throughout the summer in Kachemak Bay compared to Lynn Canal, where salinity decreased from $\sim 30 \mathrm{ppt}$ at most sites in the spring to $\sim 15 \mathrm{ppt}$ at most sites by midsummer. Higher average salinity in Kachemak Bay arises from a more direct connection to the Gulf of Alaska (Fig. 1). Within Kachemak Bay, differences in fish communities were partially explained by temperature and river discharge, whereas in Lynn Canal, temperature and salinity were the most influential environmental variables. The importance of salinity in Lynn Canal may be partially attributed to the Lemon Creek site, which in addition to having much lower salinity values, had the lowest species diversity of the Lynn Canal sites.

Our environmental sampling did not fully capture habitat differences among sites that could explain some of the ecological variation. Unexplained site differences in Kachemak Bay accounted for more of the variation in fish communities than water quality parameters (temperature, salinity, turbidity, and discharge). For example, substrate characteristics may have accounted for some of the greater within-region variability in species composition in Kachemak Bay compared to Lynn Canal. Sites in Lynn Canal had more similar substrate types composed of sand, mud, and silt, whereas sites in Kachemak Bay were characterized by a wider variety of mud, sand, and cobble. Substrate can be a determinant of fish communities, particularly for groundfishes that spend extended periods on the bottom or burrowed into substrate (Moles and Norcross 1995; Horne and Campana 1989). Variable substrate type in Kachemak Bay may also have contributed to higher sampling variance, as pulling a beach seine over irregular cobble-sand-mud substrate can create opportunities for fish to escape beneath the net. Therefore, future studies would benefit from more detailed characterization of substrate grain size and type at sampling locations.

There were significant differences in species composition among months, with the most notable shift between the April-July and August-September periods. These seasonal differences can partially be attributed to the influx of juvenile Pacific salmon from both wild and hatchery populations in April, May, and June. Wild-born Pacific salmon outmigrate from freshwater to saltwater as fry in the spring and early summer (Quinn 2018). In the vicinity of our Lynn Canal study sites, the Macaulay Salmon Hatchery releases millions of juvenile chum salmon $(O$. keta), along with more limited releases of coho salmon and Chinook salmon $(O$. tshawytscha), into estuaries in April and May (Duncan and Beaudreau 2019; Stopha 2019). Hatcheries in the Kachemak Bay area, such as the Tutka Bay Lagoon Hatchery, release pink salmon (O. gorbuscha) and sockeye salmon (O. nerka) in the early summer (ADFG 2019). The anthropogenic input of these hatchery Pacific salmon to the estuary sites complicates the detection of environmental drivers of community structure. The seasonal flux of hatchery salmon to estuaries can also indirectly affect community composition through aggregative responses of marine consumers (e.g., humpback whales and piscivorous fishes feeding on released hatchery salmon; Chenoweth et al. 2017; Duncan and Beaudreau 2019). Other fish migrants move into and out of the estuary seasonally, including larval herring and smelt (Johnson et al. 2015), but juvenile Pacific salmon seem to be driving the biggest seasonal shifts in species composition, according to our vector fitting analysis.
Fig. 5 Mean starry flounder lengths over spring and summer for Lynn Canal sites, 2014-2019. Points are color coded by mean water temperature measured on the sampling date. Solid lines are fitted loess regression smoothing functions to visualize seasonal trends. Gray bands show the $95 \%$ confidence interval

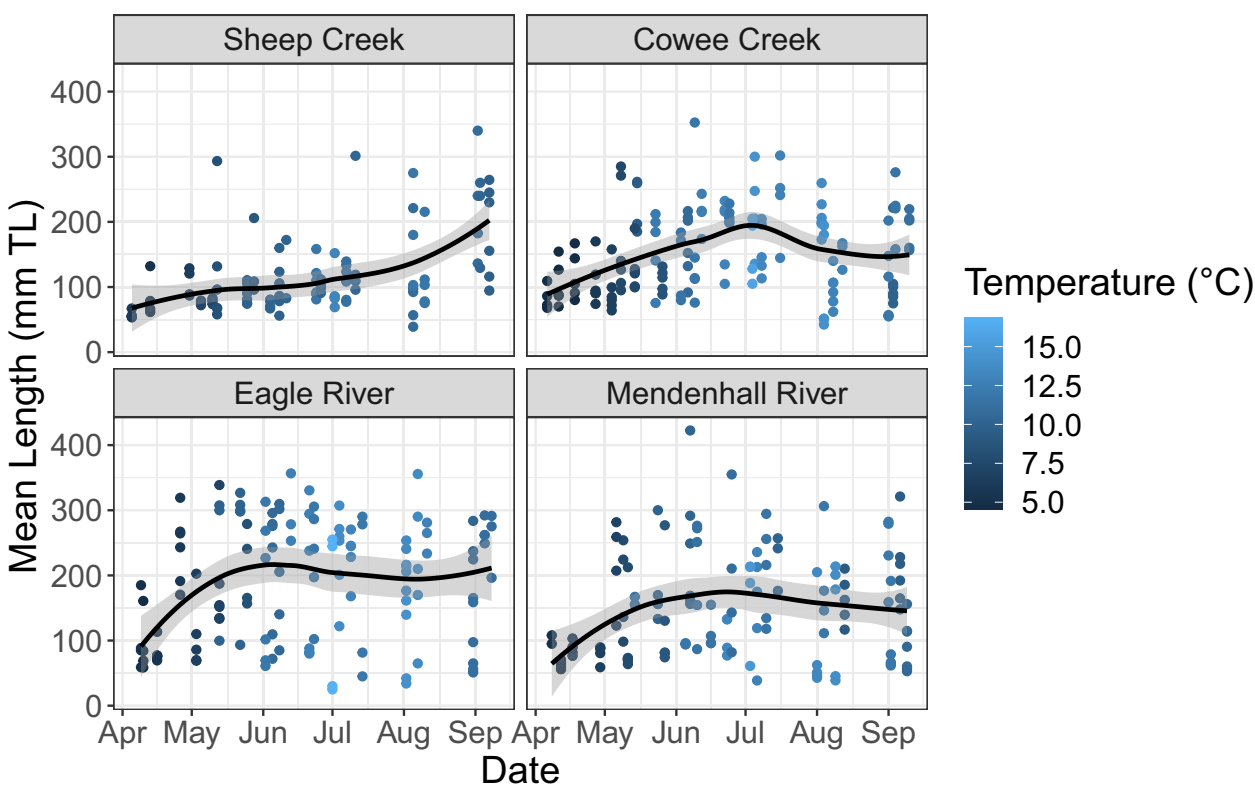




\section{Spatiotemporal and Environmental Drivers of Fish Body Size}

Seasonal trends in temperature may influence estuarine fish assemblages at multiple ecological scales, from community structure to individual growth (Beauchamp et al. 2007; Fisher et al. 2007; Pirtle et al. 2012; Wendler et al. 2017). In this study, temperature helped to explain differences in GOA fish communities and was also an important predictor of starry flounder length in Lynn Canal. For staghorn sculpin, mean length was better explained by site-specific seasonal trends (i.e., site $\times$ day of year interaction term) than temperature. The increasing mean lengths of starry flounder and staghorn sculpin throughout the summer likely reflects both ontogeny (i.e., juvenile fish growing over the course of the summer) and temperature-dependent growth (Clarke and Johnston 1999). Length is the result of thermal history, and not simply the temperature at the time of sampling, and future studies may benefit from continuous temperature measurements that allow for calculation of degree days to assess the effects of past temperatures on growth. A caveat to our length analysis is that we were not able to differentiate changes in size that arise from actual growth of individual cohorts, apparent growth due to recruitment pulses of multiple cohorts, immigration into and out of the nearshore, size-selective predation, or some combination. Based on inspection of length frequency histograms, in some cases, we were able to infer changes in mean length that were likely attributed to growth of a dominant cohort (e.g., staghorn sculpin and starry flounder at the Sheep Creek site; Fig. S1). However, in other cases, changes in mean length were more difficult to attribute to growth, as shifts seemed to arise from different age classes moving into the estuary (e.g., staghorn sculpin and starry flounder at the Mendenhall River site; Fig. S2). These patterns appear to be both species and site-specific, with stronger positive trends in mean and modal lengths for staghorn sculpins at the sites experiencing lower glacial runoff. While limited movement data exist for these species, staghorn sculpins may be more sedentary than starry flounder based on preliminary tagging data in Lynn Canal (C. Bergstrom, personal communication), and their size structure may therefore be more reflective of local thermal conditions. Persistent input of colder water at outflow of glacial rivers may also create an environment of low growth, particularly during periods of peak flow in late summer, when we saw asymptotic lengths for both species.

Differences in staghorn sculpin length distributions among years, as indicated by our model results, may also be explained by interannual temperature differences (Fig. S9). For example, 2014 was a cool, wet summer, whereas the summer of 2019 was hot and dry (NOAA 2020). While the mean water temperature measured across sites for both sampling seasons was $11^{\circ} \mathrm{C}(\mathrm{SD}=2.4)$, the maximum water temperature we measured in 2014 was $12.8^{\circ} \mathrm{C}$ and the maximum water temperature we measured in 2019 was $16.8^{\circ} \mathrm{C}$. In 2014 , the overall mean length for staghorn sculpins was $129.7 \mathrm{~mm}(\mathrm{SD}=92.1)$, while the mean length in 2019 was $105.2 \mathrm{~mm}(\mathrm{SD}=61.3)$. As water temperatures in shallow areas increase, mobile fishes may seek cooler water in deeper habitats to avoid higher metabolic demands and physiological stress (e.g., Dulvy et al. 2008). Our observation of fewer large sculpins in 2019, one of the warmest recorded years in Southeast Alaska (ACRC 2019), may have resulted from movement of individuals into deeper thermal refuges. Smaller sculpins may also prefer cooler water temperatures, but are less mobile and could be limited by other factors including depth and salinity, as juvenile staghorn sculpins are known to rear in fresh and brackish water (Johnson et al. 2015).

The best explanatory models for starry flounder length included environmental variables rather than space/time variables. This finding offers a helpful lesson for other observational studies in ecology. Common categorical factors used to explain ecological variation, such as site and month, may be poor proxies for dynamic environmental processes driving seasonal and spatial changes in fish communities. When possible, key environmental variables like temperature and salinity should be directly measured and included in analyses of size structure. Temperature, salinity, and turbidity were positively related to starry flounder length; however, partial effects plots indicated a weaker positive relationship between starry flounder length and salinity compared to the positive correlations with temperature and turbidity. Starry flounder are highly freshwater tolerant (Takeda and Tanaka 2007), as supported by our vector-fitting analysis, and prefer fine substrates that allow them to burrow and camouflage (Moles and Norcross 1995). Furthermore, starry flounder diet is largely made up of small infauna found in fine sediment (McCall 1992), such as that found at glacial river deltas, which are associated with higher turbidities.

\section{Implications of Changing Conditions for Estuary Communities}

Greater differences in community composition between regions, compared to within regions, suggests that climate change will not have uniform impacts across GOA estuaries but is dependent on the interaction of landscape features (e.g., presence of glaciers) and marine drivers (Pitman et al. 2020). However, the fish species that are most likely to do well with continued glacier recession are those that have the physiological flexibility and mobility to live in a range of environments, such as the groundfish species we observed in high densities. Staghorn sculpin have been collected from water temperatures between 1.1 and $18.7^{\circ} \mathrm{C}$ (Kaschner et al. 2016) and show no physiological stress in salinities ranging from $15-30 \mathrm{ppt}$, even 
tolerating 0 ppt for short periods (Henriksson et al. 2008). This wide range of tolerable temperatures and salinities suggests that staghorn sculpin may be resilient to near-term environmental changes; however, the maximum water temperature recorded during the 2019 sampling season was $17^{\circ} \mathrm{C}$, indicating that temperatures may intermittently reach uninhabitable levels in some shallow waters. Similarly, starry flounder were assessed to have low overall vulnerability and low climate exposure in the Bering Sea, largely because of their high potential for distribution shifts, should habitat conditions change (Spencer et al. 2019). In contrast, temporary estuarine residents like juvenile Pacific salmon may have less flexibility, as their optimal temperature window for growth and development is between 12 and $14{ }^{\circ} \mathrm{C}$ (Richter and Kolmes 2005), a range that leaves little room for accommodating increasing maximum summer temperatures in the Gulf of Alaska. This temperature threshold is of particular concern in the estuaries fed by smaller, non-glacial rivers, where summer water temperatures are more likely to exceed physiological tolerances of resident fishes, compared to those buffered by glacier meltwater (Fellman et al. 2015). Because of this estuary-specific variability, it is important to continue to monitor GOA estuaries for changing conditions that affect habitat availability for sensitive species. The findings from this study lay the groundwork for understanding how Alaska's coastal ecosystems and other nearshore ecosystems in northern latitudes may respond to change in the coming decades.

Supplementary Information The online version contains supplementary material available at https://doi.org/10.1007/s12237-022-01057-x.

Acknowledgements We are grateful to M. Bargas, A. Bidlack, M. Callahan, J. Gordon, C. Guo, S. King, M.K. McCabe, E. Whitney, E. Williamson, and B. Zhang for their invaluable contributions to field and lab work. Thanks to C. Sergeant for providing the map. This work would not have been possible without the assistance of volunteers in the communities of Juneau, Homer, and Fairbanks. We appreciate comments from two anonymous reviewers, which helped to improve the paper.

Funding This material is based upon work supported by the National Science Foundation under awards \#OIA-1208927 and \#OIA-1757348 and by the State of Alaska. The research was also sponsored by Alaska Sea Grant under Grant NA14OAR4170079 (Projects R/32-07 and RR/14-01) and from the University of Alaska with state-appropriated funds. Additional funding was provided to N. Lundstrom by the North Pacific Research Board through a Graduate Student Research Award.

Open Access This article is licensed under a Creative Commons Attribution 4.0 International License, which permits use, sharing, adaptation, distribution and reproduction in any medium or format, as long as you give appropriate credit to the original author(s) and the source, provide a link to the Creative Commons licence, and indicate if changes were made. The images or other third party material in this article are included in the article's Creative Commons licence, unless indicated otherwise in a credit line to the material. If material is not included in the article's Creative Commons licence and your intended use is not permitted by statutory regulation or exceeds the permitted use, you will need to obtain permission directly from the copyright holder. To view a copy of this licence, visit http://creativecommons.org/licenses/by/4.0/.

\section{References}

Abookire, A.A., and B.L. Norcross. 1998. Depth and substrate as determinants of distribution of juvenile flathead sole (Hippoglossoides elassodon) and rock sole (Pleuronectes bilineatus), in Kachemak Bay, Alaska. Journal of Sea Research 39: 113-123.

Abookire, A.A., J.F. Piatt, and M.D. Robards. 2000. Nearshore fish distributions in an Alaskan estuary in relation to stratification, temperature and salinity. Estuarine, Coastal, and Shelf Science 51: 45-59.

ACRC. 2019. 2019 Alaska climate review. Fairbanks, Alaska.

ADFG. 2019. 2019 Annual management plan, Tutka Bay Lagoon Hatchery. Cook Inlet Aquaculture Association.

Anderson, M.J. 2001. A new method for non-parametric multivariate analysis of variance. Austral Ecology 26: 32-46.

Anderson, M.J., and D.C.I. Walsh. 2013. PERMANOVA, ANOSIM, and the Mantel test in the face of heterogeneous dispersions: What null hypothesis are you testing? Ecological Monographs 83 (4): 557-574.

Barbier, E.B., S.D. Hacker, C. Kennedy, E.W. Koch, A.C. Stier, and B.R. Silliman. 2011. The value of estuarine and coastal ecosystem services. Ecological Monographs 81: 169-193.

Beauchamp, D.A., A.D. Cross, J. Armstrong, K.W. Myers, J.H.H. Moss, J. Boldt, and L.J. Haldorson. 2007. Bioenergetic responses by Pacific salmon to climate and ecosystem variation. North Pacific Anadromous Fish Commission 4: 257-269.

Beaudreau, A.H., C.A. Bergstrom, E.J. Whitney, D.H. Duncan, and N.C. Lundstrom. In Review. Seasonal and interannual variation in high-latitude estuarine fish community structure along a glacial to non-glacial watershed gradient in Southeast Alaska. Environmental Biology of Fishes.

Bienfang, P.K., and D.A. Ziemann. 1995. APPRISE: A multi-year investigation of environmental variation and its effects on larval recruitment. pp 483-487 In: Beamish, R. (Ed). Climate Change and Northern Fish Populations. Canadian Special Publication of Fisheries and Aquatic Sciences 121.

Burnham, K.P., and D.R. Anderson. 2002. Model selection and multimodel inference: A practical information-theoretic approach, 2nd ed. New York: Springer-Verlag.

Caffrey, J.M., T.P. Chapin, H.W. Jannasch, and J.C. Haskins. 2007. High nutrient pulses, tidal mixing and biological response in a small California estuary: Variability in nutrient concentrations from decadal to hourly time scales. Estuarine, Coastal and Shelf Science 71: 368-380.

Chenoweth, E.M., J.M. Straley, M.V. McPhee, S. Atkinson, and S. Reifenstuhl. 2017. Humpback whales feed on hatchery-released juvenile salmon. Royal Society Open Science 4: 1-10.

Clarke, A., and N.M. Johnston. 1999. Scaling of metabolic rate with body mass and temperature in teleost fish. Journal of Animal Ecology 68: 893-905.

Clarke, K.R., R.N. Gorley, P.J. Sommerfield, and R.M. Warwick. 2014. Change in marine communities: an approach to statistical analysis and interpretation. 3rd edition. PRIMER-E Ltd, Plymouth.

Dulvy, N.K., S.I. Rogers, S. Jennings, V. Stelzenmüller, S.R. Dye, and H.R. Skjoldal. 2008. Climate change and deepening of the North Sea fish assemblage: A biotic indicator of warming seas. Journal of Applied Ecology 45: 1029-1039.

Duncan, D.H., and A.H. Beaudreau. 2019. Spatiotemporal variation and size-selective predation on hatchery- and wild-born juvenile 
chum salmon at marine entry by nearshore fishes in Southeast Alaska. Marine and Coastal Fisheries 11: 372-390.

Elliott, M., and A.K. Whitfield. 2011. Challenging paradigms in estuarine ecology and management. Estuarine, Coastal and Shelf Science 94: 306-314.

Fellman, J.B., S. Nagorski, S. Pyare, A.W. Vermilyea, D. Scott, and E. Hood. 2014. Stream temperature response to variable glacier coverage in coastal watersheds of Southeast Alaska. Hydrological Processes 28: 2062-2073.

Fellman, J.B., E. Hood, W. Dryer, and S. Pyare. 2015. Stream physical characteristics impact habitat quality for Pacific salmon in two temperate coastal watersheds. PLoS One 10(7): e0132652.

Field, C., and C. Walker. 2003. A site profile of the Kachemak Bay Research Reserve: a unit of the National Estuarine Research Reserve system. Kachemak Bay Research Reserve, Homer, AK.

Fisher, J., M. Trudel, A. Ammann, J. Orsi, J.J. Piccolo, C. Bucher, E. Casillas, J.A. Harding, and R.B. Macfarlane. 2007. Comparisons of the coastal distributions and abundances of juvenile Pacific salmon from central California to the northern Gulf of Alaska. American Fisheries Society Symposium 57: 31-80.

Fukuwaka, M., and T. Suzuki. 1998. Role of a riverine plume as a nursery area for chum salmon Oncorhynchus keta. Marine Ecology Progress Series 173: 289-297.

Gillanders, B.M., T.S. Elsdon, I.A. Halliday, G.P. Jenkins, J.B. Robins, and F.J. Valesini. 2011. Potential effects of climate change on Australian estuaries and fish utilising estuaries: A review. Marine and Freshwater Research 62: 1115-1131.

Grimaldo, L., J. Burns, R.E. Miller, A. Kalmbach, A. Smith, J. Hassrick, and C. Brennan. 2020. Forage fish larvae distribution and habitat use during contrasting years of low and high freshwater flow in the San Francisco estuary. San Francisco Estuary and Watershed Science 18: 1-20.

Guo, C. 2019. The influence of water flow, water conditions, and seasonality on fish communities in estuarine nearshore habitats in Kachemak Bay, Alaska. Coastal Marine Institute Graduate Student Projects 3: 1-26.

Henriksson, P., M. Mandic, and J. G. Richards. 2008. The osmorespiratory compromise in sculpins: impaired gas exchange is associated with freshwater tolerance. Physiological and Biochemical Zoology 81.

Hood, E., and L. Berner. 2009. Effects of changing glacial coverage on the physical and biogeochemical properties of coastal streams in southeastern Alaska. Journal of Geophysical Research: Biogeosciences 114: 1-10.

Hood, E., J. Fellman, R.G.M. Spencer, P.J. Hernes, R. Edwards, D. D'amore, and D. Scott. 2009. Glaciers as a source of ancient and labile organic matter to the marine environment. Nature 462 : 1044-1047.

Horne, J.K., and S.E. Campana. 1989. Environmental factors influencing the distribution of juvenile groundfish in nearshore habitats of southwest Nova Scotia. Canadian Journal of Fisheries and Aquatic Sciences 46: 1277-1286.

Johnson, S.W., A.D. Neff, and M.R. Lindeberg. 2015. A handy field guide to the nearshore marine fishes of Alaska. NMFS: NOAA.

Kaschner, K., K. Kesner-Reyes, C. Garilao, J. Rius-Barile, T. Rees, and R. Froese. 2016. AquaMaps: predicted range maps for aquatic species. www.aquamaps.org.

Kohan, M.L., J.A. Orsi, F. Mueter, and M.V. McPhee. 2013. Variation in abundance and condition of juvenile chum salmon (Oncorhynchus keta) in the eastern Gulf of Alaska in relation to environmental variables. North Pacific Anadromous Fish Commission 9: $244-248$.

Lankford, T.E., and T.E. Targett. 1994. Suitability of estuarine nursery zones for juvenile weakfish (Cynoscion regalis): Effects of temperature and salinity on feeding, growth and survival. Marine Biology 119: 611-620.
Larsen, C.F., E. Burgess, A.A. Arendt, S. O’Neel, A.J. Johnson, and C. Kienholz. 2015. Surface melt dominates Alaska glacier mass balance. Geophysical Research Letters 42: 5902-5908.

Ljunggren, L., and A. Sandstrom. 2007. Influence of visual conditions on foraging and growth of juvenile fishes with dissimilar sensory physiology. Journal of Fish Biology 70: 1319-1334.

Lowe, M.L., M.A. Morrison, and R.B. Taylor. 2015. Harmful effects of sediment-induced turbidity on juvenile fish in estuaries. Marine Ecology Progress Series 539: 241-254.

Mahardja, B., M. J. Farruggia, B. Schreier, and T. Sommer. 2017. Evidence of a shift in the littoral fish community of the SacramentoSan Joaquin Delta. PLoS One 12(1): e0170683.

Mantua, N., I. Tohver, and A. Hamlet. 2010. Climate change impacts on streamflow extremes and summertime stream temperature and their possible consequences for freshwater salmon habitat in Washington State. Climatic Change 102: 187-223.

McCabe, K. and B. Konar. 2021. Influence of environmental attributes on intertidal community structure in glacial estuaries. Deep Sea Research. In review.

McCall, J.N. 1992. Source of harpacticoid copepods in the diet of juvenile starry flounder. Marine Ecology Progress Series 86: 41-50.

Miller, K., F. Huettmann, B. Norcross, and M. Lorenz. 2014. Multivariate random forest models of estuarine- associated fish and invertebrate communities. Marine Ecology Progress Series 500: $159-174$.

Moles, A., and B. Norcross. 1995. Sediment preference in juvenile Pacific flatfishes. Netherlands Journal of Sea Research 34: 177-182.

Morris, R.W. 1960. Temperature, salinity, and southern limits of three species of Pacific cottid fishes. Limnology and Oceanography 5: 175-179.

NOAA. 2020. NWS Forecast Office, Juneau, AK. https://www.weather. gov/ajk/.

Norcross, B.L., A. Blanchard, and B.A. Holladay. 1999. Comparison of models for defining nearshore flatfish nursery areas in Alaskan waters. Fisheries Oceanography 8: 50-67.

Norcross, B.L., B.A. Holladay, and F.J. Müter. 1995. Nursery area characteristics of pleuronectids in coastal Alaska, USA. Netherlands Journal of Sea Research 34: 161-175.

Nyitrai, D., F. Martinho, M. Dolbeth, J. Baptista, and M.A. Pardal. 2012. Trends in estuarine fish assemblages facing different environmental conditions: Combining diversity with functional attributes. Aquatic Ecology 46: 201-214.

O’Neel, S., E. Hood, A.L. Bidlack, S.W. Fleming, M.L. Arimitsu, A. Arendt, E. Burgess, C.J. Sergeant, A.H. Beaudreau, K. Timm, G.D. Hayward, J.H. Reynolds, and S. Pyare. 2015. Icefield-toocean linkages across the northern pacific coastal temperate rainforest ecosystem. BioScience 65: 499-512.

Oksanen, J., F.G. Blanchet, M. Friendly, R. Kindt, P. Legendre, D. McGlinn, P.R. Minchin, R.B. O'Hara, G.L. Simpson, P. Solymos, M.H. H. Stevens, E. Szoecs, and H. Wagner. 2019. vegan: Community Ecology Package. R package version 2.5-6. Available: https://CRAN.R-project.org/package=vegan

Pirtle, J.L., S.N. Ibarra, and G.L. Eckert. 2012. Nearshore subtidal community structure compared between inner coast and outer coast sites in Southeast Alaska. Polar Biology 35: 1889-1910.

Pitman, K.J., J.W. Moore, M.R. Sloat, A.H. Beaudreau, A.L. Bidlack, R.E. Brenner, E.W. Hood, G.R. Pess, N.J. Mantua, A.M. Milner, V. Radić, G.H. Reeves, D.E. Schindler, and D.C. Whited. 2020. Glacier retreat and Pacific salmon. BioScience 70: 220-236.

Quinn, T.P. 2018. The behavior and ecology of Pacific salmon and trout, 2nd ed. Washington: University of Washington Press.

Richter, A., and S.A. Kolmes. 2005. Maximum temperature limits for chinook, coho, and chum salmon, and steelhead trout in the Pacific Northwest. Reviews in Fisheries Science 13: 23-49. 
Scanes, E., P.R. Scanes, and P.M. Ross. 2020. Climate change rapidly warms and acidifies Australian estuaries. Nature Communications 11: 1-11.

Sergeant, C.J., J.A. Falke, R.A. Bellmore, R.A. Bellmore, and R.L. Crumley. 2020. A classification of streamflow patterns across the coastal Gulf of Alaska. Water Resources Research 56.

Sogard, S.M. 1992. Variability in growth rates of juvenile fishes in different estuarine habitats. Marine Ecology Progress Series 85: 35-53.

Spencer, P.D., A.B. Hollowed, M.F. Sigler, A.J. Hermann, and M.W. Nelson. 2019. Trait-based climate vulnerability assessments in data-rich systems: An application to eastern Bering Sea fish and invertebrate stocks. Global Change Biology 25: 3954-3971.

St. John M.A., J.S. McDonald, P.J. Harrison, R.J. Beamish, and E. Choromanski. 1992. The Fraser River plume: Some preliminary observations on the distribution of juvenile salmon, herring, and their prey. Fisheries Oceanography 1: 153-162.

Stopha, M. 2019. Alaska fisheries enhancement annual report 2018. Alaska Department of Fish and Game, Juneau, AK.

Takeda, Y., and M. Tanaka. 2007. Freshwater adaptation during larval, juvenile and immature periods of starry flounder Platichthys stellatus, stone flounder Kareius bicoloratus and their reciprocal hybrids. Journal of Fish Biology 70: 1470-1483.

Teichert, N., S. Pasquaud, A. Borja, G. Chust, A. Uriarte, and M. Lepage. 2017. Living under stressful conditions: Fish life history strategies across environmental gradients in estuaries. Estuarine, Coastal and Shelf Science 188: 18-26.

USGS. 2020. National Water Information System. https://www.usgs. gov/mission-areas/water-resources.
Ward E.J., M. Adkison, J. Couture, S.C. Dressel, M.A. Litzow, S. Moffitt, T. Hoem Neher, J. Trochta, R. Brenner. 2017. Evaluating signals of oil spill impacts, climate, and species interactions in Pacific herring and Pacific salmon populations in Prince William Sound and Copper River. Alaska Plos One 12 (3): 1-24.

Weingartner, T., L. Eisner, G.L. Eckert, and S. Danielson. 2009. Southeast Alaska: Oceanographic habitats and linkages. Journal of Biogeography 36: 387-400.

Weisberg, S. 1985. Applied linear regression. New York: Wiley.

Welsh, H.H., G.R. Hodgson, B.C. Harvey, and M.F. Roche. 2001. Distribution of juvenile coho salmon in relation to water temperatures in tributaries of the Mattole River, California. North American Journal of Fisheries Management 21: 464-470.

Wendler, G., T. Gordon, and M. Stuefer. 2017. On the precipitation and precipitation change in Alaska. Atmosphere 8: 1-10.

Whitney, E.J., A.H. Beaudreau, and D.H. Duncan. 2017. Spatial and temporal variation in the diets of Pacific staghorn sculpins related to hydrological factors in a glacially influenced estuary. Transactions of the American Fisheries Society 146: 1156-1167.

Whitney, E.J., A.H. Beaudreau, and E.R. Howe. 2018. Using stable isotopes to assess the contribution of terrestrial and riverine organic matter to diets of nearshore marine consumers in a glacially influenced estuary. Estuaries and Coasts 41: 193-205.

Wood, S.N. 2011. Fast stable restricted maximum likelihood and marginal likelihood estimation of semiparametric generalized linear models. J Royal Stat Soc 73 (1): 3-36. 